\title{
21. Yüzyılın Dünyevi Mabetlerinin Kapitalizasyonu ve Stratejik Sabotaj
}

\author{
The Capitalization of the $21^{\text {st }}$ Century Secular Temples and Strategic Sabotage
}

\author{
Burçin MIZRAK BILEN
}

Öz

Günümüzde kültür, teknoloji, tasarım ya da insan sermayesi gibi elle tutulur faydaları muğlak olan kavramlar en çok; bir şirketin, sanat eserinin, yazılımın ya da herhangi bir ürünün finansal değerini belirlemede etkin rol oynar hale gelmiştir. Bu durum da, bu muğlaklığın hem sektörde hem de akademide analiz edilebilmesi ve ölçülebilmesi çalışmalarını tetiklemiştir. Kentteki fiziksel çevrenin değerine etki eden önemli bir girdi olan "iyi tasarım"ın ne olduğu konusu ve ölçülebilme sorunsalı da, mimarlık alanında araştırma gündemini meşgul etmeye başlamıştır. Ne kadar çok elle tutulamayan fayda tespit ve ifşa edilirse, kentlerde o kadar daha çok "iyi" tasarım olacağı hakim görüşü, bu alanda araştırma yapanları çok kapsamlı modeller geliştirmeye yöneltmiştir. Fakat, 90'lardan itibaren başlamış bu çalışmalar, ne yazık ki, daha yaşanılır kentlerin oluşup gelişmesine beklenildiği gibi etki edememiştir. Bu bağlamda, finans sektörünün bu faydaları nasıl okuduğuyla ilgili daha içsel bir anlayış elde etmek için, "değerin güç teorisi" çerçevesinde, bu teorinin merkezine aldığı köksüz transnasyonel kapitalist sınıf lehine olan diferansiyel kapitalizasyon ve stratejik sabotaj kavramlarının fiziksel mekandaki izleri aranarak konu tartışmaya açılmış ve şehirlerdeki en büyük bütçeli projeleri finanse eden \%1lik mimari patronajın mülkü olan günümüz seküler mabetlerine ve uzamsal boyutlarına bu mercekten bakılmıştır. Çalışmanın çıktısı olarak; bu mabetlerin ve onları ilgilendiren uzamsal boyutun farklı aktörler için ifade ettiği farklı değerler ve bu farklı değerlerin ya da faydaların nasıl kapitalize edildiği ve neden olduğu sabotaj biçimleri detaylandırılarak açıklanmış, ayrıca literatüre provokatif bir katkı sağlamak hedeflenmiştir.

Anahtar sözcükler: \%1 in mimarisi; değerin güç teorisi; diferansiyel sermaye birikimi; kapitalizasyon; radikal sanal; stratejik sabotaj.

\section{ABSTRACT}

The concepts such as culture, technology, design, or human capital, the tangible benefits of which are vague, are mostly effective in setting the financial value of a company, a work of art, a software, or any product. This situation triggered both sectoral and academic studies intended for analyzing and measuring this vagueness. The subject of what the "good design" is, which is an important input affecting the value of the physical environment in the cities, and the problematic of its measurability started to occupy the architectural research agenda. The prevalent view that the more intangible benefits are detected and disclosed the more "good" designs the cities will have has prompted the people who conduct research in this field to develop very comprehensive models. However, these studies that started in the '90s unfortunately failed to have the expected impact on creation and development of more livable cities. In this context, to get a better insight of how the financial sector reads these benefits, the subject has been opened up for discussion within the framework of the "power theory of value", by searching for traces of the differential capitalization and strategic sabotage concepts in the physical space, which are in favor of the rootless transnational capitalist class that is at the center of this theory and the modern-day secular temples owned by the 1\% of the architectural patronage who finance the highest budget projects in cities and its spatial dimension have been seen through this lens. As an outcome of the study, different values these temples and the spatial dimension concerning them carry for different actors, and how these different values or benefits are capitalized, and the types of sabotages they cause have been explained in detail, and it has been targeted to make a provocative contribution to the literature.

Keywords: Architecture of 1\%; power theory of value; differential accumulation; capitalization; radical imaginary; strategic sabotage.

Yıldız Teknik Üniversitesi Mimarlık Fakültesi, Mimarlık Bölümü, İstanbul 


\section{Giriş}

Inşaat sektörü ve mimarlık da, tüm sektörler için olduğu gibi, zorunlu olarak parasal sistemin içinde ve bu sisteme hizmet ettikçe varlığını sürdürebilmektedir. Paranın; bir mülke sahip olanlar, o mülkü geliştirenler, tasarlayanlar, görsel olarak deneyimleyenler, işgal edenler ve onun medya aracılığıyla yayılmasını sağlayanlar üzerinde büyük etkileri ve yaptırım gücü vardır. Bir anlamda aslında, mimarlık tarihi kapitalin tarihi demektir. Ancak bu ilişki çok net olmasına rağmen, direkt olarak ve açıklıkla çok fazla incelenmemiştir. Ekonomik ve siyasal sistem, belli başlı kültürel üretimlerin talep görmesi için sahneyi kuran en önemli mekanizmadır. Bu kültürel talepler de, mimarların konuştuklarını ve gördüklerini şekillendirmektedir. Yine bu kültürel talepler, kapitalizm tarafindan, her dönemde, o kadar talep edilir bir hale getirilir ki; çoğunlukla en doğal intiyaçlarımızmış gibi bir algı yaratılır.

Kapitalizm, değişken bir olgudur ve sürekli olarak çalışma prensiplerini değiştirir. Bu mutant ve çevik sistem; sadece ekonomik yükselme ve ya düşüş dönemlerinde, ya da ekonomik faaliyetlerin rekabetçi piyasa koşulları içerisinde serbestçe ve ya devlet müdahalesiyle yürütülmesinden dolayı değil, kültür ve güçle kurduğu ilişkilerini de sürekli güncellemesinden dolayı değişim gösterir. Bu bağlamda bu çalışma kapsamında, 21. Yüzyılda gücün ve teknolojinin ortaya çıkardığı mimari eserlerle, hakim siyasal ve politik sistem olan kapitalizmin kurduğu ilişki; ekonomi politik uzmanları Prof. Dr. Jonathan Nitzan ve Prof. Dr. Shimshon Bichler'in ünlü kurumsal ekonomist Thorstein Veblen'in 19. Yüzyılda ortaya attğı teori üzerinden geliştirdiği "değerin güç teorisi" çerçevesinde, ve bu teorinin merkezine aldığı kapitalize edilme ve stratejik sabotaj kavramları aracılığıyla analiz edilmeye çalışılmıştır. Bunun için önce sektörden bağımsız olarak bu iki kavram açıklanmış ve daha sonra kavramların mimarılık alanında okumaları yapılmıştır.

\section{Kapitalizasyon ve Kapitalize Ed(il)en Güç}

Prof. Nitzan ve Prof. Bichler tarafindan kullanılan kapitalizasyon "riske göre ayarlanmış ve şimdiki değerlerine indirilmiş haliyle, gelecekte kazanılması beklenen kar ve faiz ödemelerini" ifade etmektedir. ${ }^{1}$ Kapitalizasyon veya net şimdiki değer hesaplaması, arttk çağdaş finansal kapitalizmin odak noktasını ve merkezini oluşturmaktadır. Gelecekte elde edilmesi beklenen kazançları şimdiki değerlerine indirmek, artık küresel bağlamda gündelik hayatı organize eden en temel 'ekonomik' olgudur.

Yine aynı teorisyenlere gore, kapitalist güç, kapitalizasyonla nicel olarak ölçülmektedir. Sahip olunan her varlık, sağlayacağı beklenen gelirin riske uyarlanmış bugünkü değerinin hesaplanmasıyla kapitalize edilir ve bu değer bize o varlığa sahip olanın diğer varlık sahiplerine göre relatif gü-

1 Nitzan ve Bichler, 2009, s. 8. cünü gösterir. Burda bir karşılaştırma/ ilişkilendirme vardır. Yine teoriye gore, gücün tahakkümüne maruz kalan varlıklar diferansiyel olarak birikir ve genişler. Yani tüm varlıklar aynı oranda kapitalize edilmez. Bu güç sahiplerinin, kendi mülklerinin kapitalizasyonu lehinde değişken bir zemin hazırlamaya muktedir olmaları demek. Amaç daha fazla zenginlik elde etmek değil. Ortalamayı, yani normal getiri oranını aşmak ve toplamda en büyük payı almak. Fakat Prof. Nitzan ve Prof. Bichler'in çizdiği kavramsal çerçevede, belli bir zaman dilimi içinde sahip olunan bir varlıktan elde edilecek tahmini gelirin riske ve zamana göre indirgenmesi şeklinde hesaplanan kapitalizasyon, kapitalist elitlerin kontrolünde olduğu ve oldukça muğlak ve öznel olduğu için eleştirilmektedir. Çünkü, gelecekteki bir zaman dilimi için ne kadar kazanç elde edileceği ve risk miktarı aslında tamamen belirsizdir. Yine de, kapitalizasyon/ net bugünkü değer hesaplama finans sektöründe neye yatırım yapılacağı konusunda karar vermede en çok kullanılan metottur. Nakit akışları, risk primleri ve zamanla değerde düşme (depresiasyon) gibi kapitalizasyon hesabında kullanılan üç bilinmez her türlü üretimin finans sektöründe başarısının sınanması için gerekli kriterler olarak varlığını sürdürmeye devam etmektedir.

\section{Stratejik Sabotaj ve Diğer Sektörlerdeki Okumaları}

“Prof. Nitzan ile Prof. Bichler'in sabotajla ilgili görüşleri, kurumsal iktisatçı Thorstein Veblen'in endüstri (insan ihtiyaçlarını karşılamak için faydalı malların üretimi) ile finans (tamamen parasal değerlerle, o parasal değerleri artırmak amacıyla yapılan işlemler) arasında yaptığı ayrımdan gelmektedir". ${ }^{2}$ Veblen, endüstriyi kısıtlamanın ya da sabote etmenin finans için elzem olduğunu belirtir. Aksi takdirde, kar sıfira düşecektir. Endüstrinin işleyişini finans yürütür. Veblen'in bakış açısından hareketle, Nitzan ve Bichler sermayenin özünün endüstri değil finans olduğunu savunur.

Nitzan ve Bichler, endüstriyel kapasitenin kullanımıyla sermayenin gelirdeki payı arasındaki ilişkiyi kuramsal olarak açıklamışlar ve maksimum kazanç için stratejik sınırlama konseptini kullanmışlardır. Üretim belirli bir miktara ulaşıncaya kadar, üretimin nakde dönüşümünün kar ettirdiğini, fakat o miktardan sonra en yüksek seviyesine ulaşmış kazancın giderek azaldığını iddia etmektedirler. Üretimin kar odaklı finans sektörü tarafindan asgari ya da azami ölçüde sınırlandırıldığı her iki uç durumda da kapitalist kazanç sıfira düşmektedir.

Burada neo-klasik arz talep dengesinden farklı olarak anlatılan şey stratejik bir sabotajın iş dünyası tarafindan endüstri yani üretim üzerinde uygulanmasıdır. Ve sabotajdan kasıt, sadece arz miktarındaki kısıtlama değildir. Üretim, dağıtım, değişim ve tüketim arasındaki diyalektik ilişkilerdeki her türlü gecikme, aksaklık, oluşturulan kararsızlık sabotaj olarak kavramsallaştrılmaktadır.

\footnotetext{
2 Larudee, 2011, s. 419.
} 
Stratejik sabotaj kavramı üzerinden geliştirilmiş bir sürü proje ve araştırma mevcuttur. Dünyadaki servetin \%99 unu elinde bulunduran ancak nüfusun \%1 ini oluşturan patronajın yön verdiği mimariye de aynı lensten bakmadan önce, diğer sektörlerdeki yansımalarından bahsetmek içgörüyü derinleştirmesi açısından gerekli görülmüştür. Teori ilk başta, sermayeyi en yüksek gelirli \%1 lik populasyonun ve en zengin 500 şirketin lehine kaydıran yüksek işsizlik oranları ve istihdamdaki büyümede azalma, ${ }^{3}$ petrol üreten hükümetlerin ve öncü petrol şirketlerinin lehine geliri yeniden dağıttrken bölgede savaşa neden olan ve dünyayı dengesizleştiren Orta Doğu'daki süregelen enerji çattşmaları, ${ }^{4}$ yerel ve küresel eşitsizlikleri derinleştirip sermaye birikimini arttırırken ulusal populasyonları karşı karşıya getiren mülkiyetin küreselleşmesi, ${ }^{5}$ gibi büyük ölçekte yansımaları olan sorunları ele alarak sınanmıştır. Fakat daha sonra, dünyanın öncü tahıl ticareti yapan şirketlerinin ve tahıl üreticilerinin gelirini arttırırken gelişmekte olan ülkelerdeki kitlesel açlığa neden olan artan gıda fiyatları ve artan besin fiyatlarındaki oynaklık, ${ }^{6}$ gıda ve ilaç devlerinin karlarını şişirirken küresel obezite salgınını körükleyen besin değeri düşük gıdaların ve abur cuburun yaygınlaşması, ${ }^{7}$ Hollywood'un başlıca film stüdyolarının yatırımcı riskini azaltırken seyirciyi zaafa uğratan Hollywood'un artistik özerkliği üzerindeki artan kısıtlamalar, ${ }^{8}$ öncelikle altın madenciliği yapan şirketlerin sonra da askeri harcamaları finanse eden büyük şirketlerin sermaye birikimini yarım yüzyıldan beri sigorta altına alan İsrail'in Filistin'i işgali ve Güney Afrika'daki ırkçı rejim ${ }^{9}$ gibi daha spesifik konulara yönelmiştir. Yani güç-mülk sahipleri ya da köksüz ulusaşırı kapitalist elitler, diferansiyel sermaye birikimlerini arttrmak ve yatırımc risklerini azaltmak ve güce karşı oluşacak direnci kontrol altında tutmak için, sektöründen bağımsız olarak her türlü üretimin miktarını ve kalitesini kısıtlamaktadırlar. Bu makalede de aynı sabotajın, köksüz ulusaşırı elitlerin yani \%1 i oluşturan mimari patronajın sermaye birikimlerindeki büyüme lehine, paranın ve teknolojinin dünyevi mabetleri olan kentsel ikonlar üzerinde nasıl uygulandığı tartışmaya açılacaktır. Ve tartışma, bu mabetlerin ve onları ilgilendiren uzamsal boyutun farklı aktörler için ifade ettiği farklı değer ve faydaların nasıl kapitalize edildiği üzerinden, verilen örnekler ve yapılan uzman görüşmeleriyle yürütülecektir.

\section{Kapitalize Edilebilen Faydalar ve Aktörler Üzerinden "lyi Tasarım”ın Tanımı}

Rem Koolhaas her ölçekten projesine yer verdiği S, M, L, XL adlı kitabında "Aramızda, başarılı mı yoksa başarısız mı olduğumuza hükmetmemizi sağlayacak referanslara sahip olanımız var mı?" diye sormuştur. ${ }^{10}$

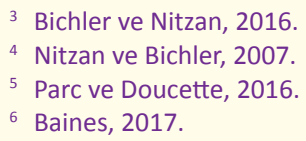

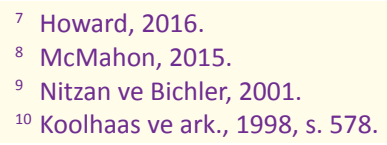

İş sektörünün, mimari tasarımın faydalarının doğruluğunu kanıtlamak ve bir anlamda da başarısını ölçmek için kullandığı araç kapitalizasyon, yani net şimdiki değer hesaplama sürecinin kendisidir. Bu risk ve nakit akışı odaklı değerleme yöntemi, 'yatırım yöntemi'/'indirimli nakit akışı analizi' veya gayrimenkul değerleme sektöründe 'gelir yöntemi' olarak farklı isimlerle anılmaktadır. Herhangi bir şeyden, bir şehir parselinden, bir bina ya da konser salonundan belirli bir süre için elde edilen gelir şimdiki değerine indirilmektedir.

Yani, bir valığın sahip olduğu her türlü özellik birşekilde, o varlığa sahip olanlar için, parasal ve iktisadi bir değer üretebiliyorsa, ya da üretebildiği ölçüde başarılı olmaktadır. İşte bu ölçüm şekli ve yarattı̆ı başarı kıstası, mal sahibi değil ama hak sahibi paydaşlar için, mimari ve özellikle kentsel mekan üretiminin kültürel, sosyal ve çevresel ürettiği ya da üretme potansiyeli taşıdığı pek çok değeri sabote etmektedir.

Binaların ekonomik randıman ve değeri ölçme çalışmaları 60 larda başlamıştır. Başlangıçta, akademi ve endüstri, yapı elemanlarının maliyet-fayda analizlerine odaklanmıştr. Ölçüm araçları, inşaat masrafları ve operasyon cetvelleridir. 70'li yılların sonlarına doğru maliyet modelleme ve nakit akış tahmini uygulamaya konulmuştur. $80^{\prime}$ li yıllar yaşam dönemi maliyetlemesi ve değer mühendisliği uygulamalarını görmüştür. $90^{\prime}$ ı yıllar da tasarım çalışmalarının katma değerine tanık olmuştur. 2000 lerden itibaren, sürdürülebilirlik, kültür, imaj gibi kavramlar tasarımın değerini arttırıcı bir mekanizma olarak araştırmaların odağı haline gelmiştir. ${ }^{11}$

Bu durum da beraberinde, iyi bir tasarımın elle tutulamayan faydaları nelerdir sorusunu getirmiştir. Literatürdeki hakim görüş, bir binanın tasırımının içinde gömülü olan değerlerin ifşası arttkça, binaların tasarımının da iyileşeceği yönündedir. ${ }^{12-14}$ Fakat, bu hakim görüşle çelişen, iyi tasarımın içinde barındırdığı değerlerin tüm paydaşlar ya da aktörler için aynı şeyi ifade etmemesi ve aynı faydaları sağlamaması görüşü, yani fark gösterir olması, bu çalışmayla birlikte yapılı çevrede izleri aranan sabotaj kavramının en temel nedeni olarak görülmüştür. Bu çelişkiyi detaylandırmak ve bu farklı görüşü kapsamlıca güçlendirmek için aşağıdaki aktör-fayda-kapitalizasyon partikülleri (kapitalizasyon hesabında kullanılan formülün değişkenleri) arayüzü hazırlanmış ve önerilen ilişkiler ağıyla konu paranın ve teknolojinin dünyevi mabetleri olan örnekler üzerinden tartı̧ılmıştır (Şekil 1).

İyi tasarımın elle tutulamayan faydaları bu çalışma için hazırlanan arayüzde belirtildiği gibi, her paydaş için farklılık göstermektedir. Ancak görüldügü gibi kapitalizasyon partikülleri olarak tanımlanan nakit akışı, risk primi ve za-

\footnotetext{
${ }^{11}$ Loe, 2000. ${ }^{12}$ Macmillan, 2006. ${ }^{13}$ Lützkendorf, 2008. ${ }^{14}$ Sayce, 2012
} 


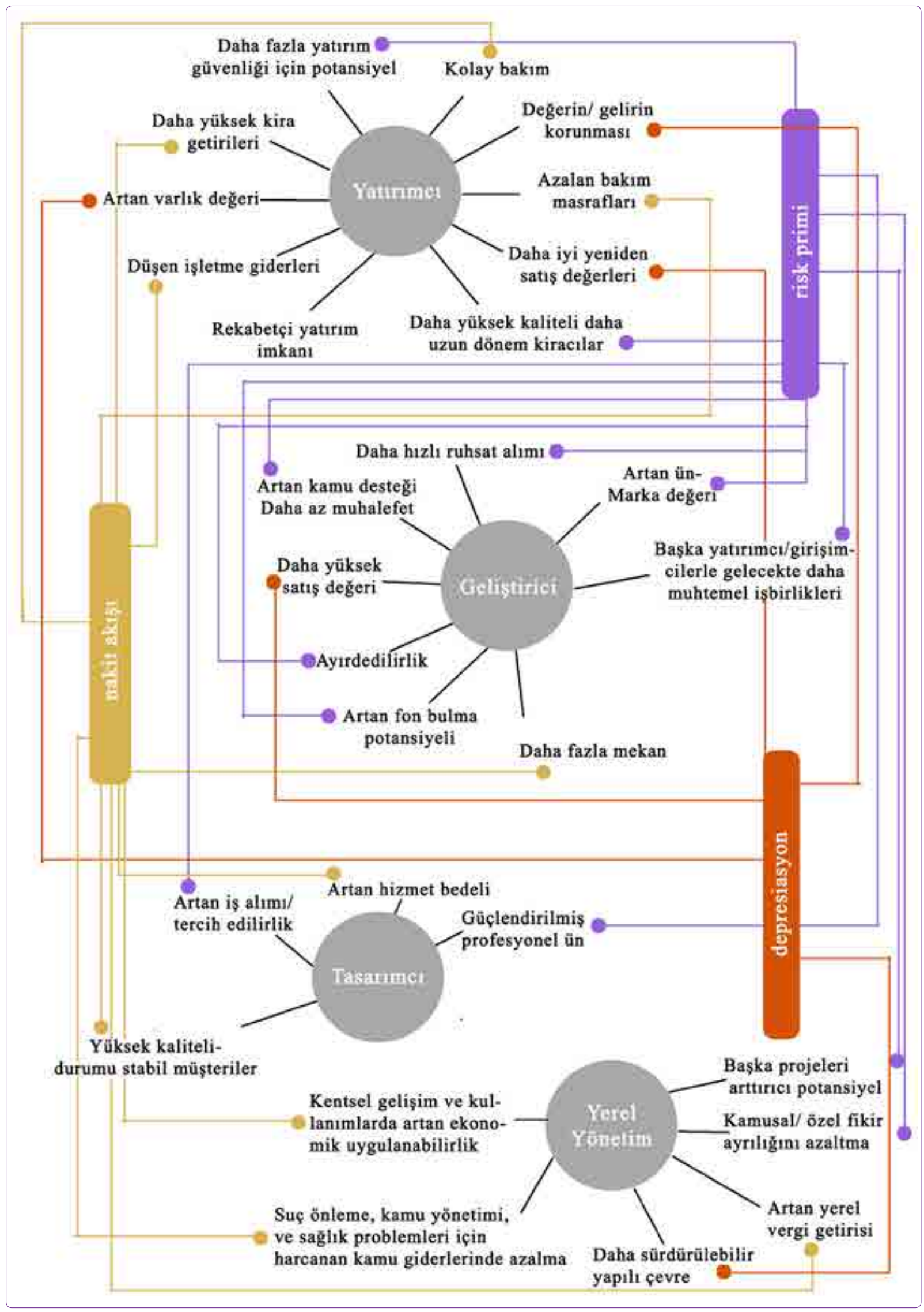

Şekil 1. Aktör-fayda-kapitlizasyon partikülleri arayüzü (yazar tarafından geliştirilmiştir). 
manla değerde düşme (depresiasyon) için anlamlı birer girdi oluşturabilen bu faydalar; yatırımcı, geliştirici, tasarımcı ve yerel yönetim için olan faydalardır. Üretimde, bakım ve işletmede çalışanlar ve bir üst ölçekte de toplum için iyi bir tasarımın ya da iyi bir projenin sağlaması gereken avantaj ve faydalar bu arayüzde yer alamamaktadır. Bunun nedeni, bu faydaların oyun kurucu ulusaşırı kapitalist sınıf için kapitalize edilememesidir. Kentte herkes için artan kültürel canlılık, daha adil kullanımlı/ erişilebilir kentsel mekan, azalan stres, artan yaşam kalitesi, azalan kirlilik, daha kapsayıcı kamusal alanlar, artan aidiyet hissi, ne yazık ki arayüzdeki aktörler için üretimdeki başarının birincil göstergeleri olamamakta, çünkü kapitalize edilememektedirler. Bu da kentte mekan üretimindeki sabotaja sebep olmaktadır. Öyleyse; mülkün sahibi kim; kentin sahibi kentli mi; neleri, kim için kapitalize edebiliyoruz sorularına verilecek dürüst cevaplar; ancak, bize bugün neden bu içine kapanık dünyevi mabetlerin ve yapı adalarının ürediğiyle ilgili ikna edici bir açıklama sunabilir. Kapitalizasyon bir mülkün sahip olduğu özelliklerin ve ürettiği faydaların, o mülkün sahipleri, finansörleri için riske ve nakit akışına yani rakamlara indirgenmesi üzerinden hesaplanabiliyorsa, harhangi bir mülkün sahibi olmayanlar için o üretimden fayda sağlanabilir mi? Yani, tasarımcı kendi emeğinin karşılığında başlı başına bir spekülasyon konusu olacak miktardaki ücretini alır ve kendini dünyanın sayılı mimarları arasına sokar ya da yerini sağlamlaştrırken, yatırımcı/geliştirici yaptığı yatıııın/ üretimin karşılığında dünya çapında ün, itibar, güç ve bir bina kazanırken, yerel yönetimler yatrımları ve verdikleri izinler karşılığında vergi gelirlerini arttırır ve sorumlusu oldukları kenti tüm dünyaya pazarlamaya yetecek kadar farklı yeni bir meta edinirken; binayı kullanma ayrıcalığını elde edebilenler dışında, kentlinin eline o ürüne dışarıdan bakıp övünmekten ya da şikayet etmekten başka herhangi bir şey geçmekte midir?

\section{\%1 İçin Kapitalize Edilen Yer ve Yapı}

Tarih boyunca, zenginliğin ve gücün simgesi olan mimari ikonlar kendileri için özel bir yer bulmuştur. Mısır piramitleri, Mezapotamya'daki zigguratlar, Atina'daki Partenon, Avrupa'daki Ortaçağ katedralleri bu anlamda ilk akla gelenlerdendir. Fakat bu yapıları, bu çalışma kapsamında incelenen 21. Yüzyıldaki paranın dünyevi mabetlerinden ayıran farklar vardır. 21. Yüzyılın mabetleri arttk dinsel, tanrısal ya da kutsal değer yaratmaktan çok, iktisadi değer üretmek içindir. Oysa ki piramitler, ziguratlar ya da katedraller yapılageldikleri dönemlerde belli aktörler için kapitalize edilebilmekten ziyade; işlevsellikleri, semiyotik ve simgesel değerleriyle herkes için önem ve anlam kazanmışlardır. Dolayısıyla da, işlevselliklerini ve sembolik değerlerini korudukları ölçüde varolmuşlardır. 1694 yılında İngiltere Bankası'nın kurulmasıyla, ve insanlığın paradan para kazanabileceğini keşfetmesiyle, yani kapitalizmin ortaya çıkmasıyla, tüm bu işlevsel, semiyotik ve simgesel faydalara ek, parasal gerekçeler ve faydalar da oyuna eklenen bir parametre olmuş ve zamanla önem sırasında en üste yerleşmiştir. Bu çalışma kapsamında 'dünyevi mabetler' olarak adlandırılan yapılar da, bu kuralları yeniden belirlenen oyunda (kapitalist sistemde), oyun kurucuların (kapitalistlerin) en güçlü destekçisi olmuştur. "Belirli bir coğrafi bölgede aşırı sermaye birikimi olarak tezahür eden kapitalizm, içsel çelişkilerini aşmak için "uzamsal çözüme" başvurmuştur. Ve coğrafi yayılma, uzamsal düzenlemeler ve eşitsiz coğrafi gelişmenin bünyevi imkanlarıyla, bir siyasal-ekonomik sistem olarak işlerliğini devam ettirebilmiştir". ${ }^{15}$ 19. yy da, Paris ve Londra gibi kentler, buralarda hızla artan nüfusun ihtiyaçlarına cevap verecek şekilde, ancak esasen "uzamsal çözüm" olarak yaratılmıştır. Emile Zola 1871 de yazılmış ve 1976 da dilimize 'Oyun Bitti' adıyla çevrilmiş romanında, Paris'te tekelci-sermayenin kentleşme sürecindeki yağmacı üslubunun canlı bir tasvirini yapmış ve borsada yapılan spekülasyon gibi, yeni mahalleler üzerinde de spekülasyon yapıldığını ve koskocaman bir kumar oynandığını yazmıştır. ${ }^{16} 20$. yüzyılın başından itibaren, Avrupa henüz sivil mimariyle ve kentsel planlama ve koruma kurallarını belirlemeyle uğraşırken, Amerika'da, halkın yokluk ve işsizlikle savaştı̆ı fakat büyük şirketlerin diferansiyel kapitalizasyonun en fazla olduğu büyük buhran yıllarında, özel sermayenin New York Manhattan'da kendi özel mabetlerini yaratmasını sağlayan çok katlı şirket mimarisi görülmeye başlanmıştır. Patronlarının isimlerini taşıyan Chanin Binası, Rockefeller Merkez Binası, Seagram Binası, Woolworth Binası ve Trump Binası gibi gökdelenler; bu tipolojinin ilk örneklerini oluşturmuştur. 1943 yılında Solomon R. Guggenheim'ın sanat danışmanı Hilla Rebay, Frank Lloyd Wright'a, patronunun New York Guggenheim Müzesi için adeta bir "anıt", "spiritüel bir tapınak" gibi görünecek bir yapı tasarlatmak istediğini söylemiş ve Wright bu yapının tasarımı için 15 sene boyunca çalışmıştı. ${ }^{17} 20$. Yüzyıl Amerikan kapitalizminin zengin patronajı, doğup büyüdüğü şehre bağıılığını gösterme, değer katma, sorumluluk alma ve tüm çalışanlarına kaliteli çalışma alanı temin etme gibi motivasyonlarla, o dönemki seküler mabetlerin oluşmasını sağlamış; lobilerini, çatı teraslarını, açık alanlarını, Amerika'nın en muazzam kamusal alanları olacak nitelikte, sanat eserleriyle süsleyerek kamunun kullanımına açmıştır. Bugün Rockfeller Merkez Binası'nda halen yılın belli zamanlarında ülkenin en dikkat çekici etkinlikleri gerçekleştirilmeye devam etmektedir. Ancak 1960'lardan sonra, yavaş yavaş bu gökdelen mimarisi banalleşmeye, yatırımcı için önemini ve gücünü yitirmeye başlamıştı. Şehirlerde yeni iş merkezi bölgelerinin oluşabilmesi amacıyla, şirketler yıllarca varlıklarını sürdürdükleri lokasyonlara

\footnotetext{
${ }^{15}$ Harvey ve Gambetti, 2008, s. $40 . \quad{ }^{17}$ Kaika, 2011, s. 968-992.

16 Zola, 1976, s. 94.
} 
sadaketlerini sürdürememiş; el değiştiren köksüz ulusaşırı patronaj, artk herhangi bir şehre ya da yere ait olmak ve oranın sosyal ve politik yaşamına karşı sorumluluk hissetmek gerekliliğini üzerinden atmış, tamamen "uzamsal bir çözüm" üretmek, kentlere yeni finans merkezleri kazandırmak adına şehir merkezinden ayrılmış, şehrin eteklerine yerleşmiştir. Binalar boşaltılmış, yıkılmış ve yeni sahipleri için yeniden tasarlanıp, inşa edilmişlerdir. Yapımı 1908 yılında tamamlanan New York Aşağı Manhattan'daki 47 katIı Singer Binası, 1968 yılında yerine yapılacak One Liberty Plaza için yıkılmıştır. Yapımı 1925 yılında tamamlanan 45 katı Şikago'daki Morrison Oteli, 1965 yılında yerine yapılacak Bank One Plaza için; yapımı 1908 yılında tamamlanan New York'taki 33 katlı City Investing Binası, 1968 yılında yerine yapılacak One Liberty Plaza için; yapımı 1927 yılında tamamlanan 33 katlı New York'taki Savoy-Plaza Otel, 1965 yılında yerine yapılacak Genenral Motors Binası için yıkılmışt ${ }^{18}{ }^{18} \mathrm{Ne}$ yazık ki, bu yıkım faaliyetleri sonraki yıllarda da hep el değiştiren patronaj ve değişen beklentiler dolayısıyla devam etmiştir. Kimlikleri ve adresleri belli, hatta iş yapmak dışında verdiği sosyal hizmetlerle toplumda belirli bir popüleritesi ve saygınlığı olan patronların yerini; değil patronları, merkezlerinin bile nerede olduğu tam olarak bilinmeyen, ancak dünyanın önemli metropollerinin finans bölgelerinde iş kuleleri olan devasa şirketler almıştır. Bugünlerde de Manhattan'da bulunan, Phillip Johnson'un 1984 yılında tasarladığı, postmodern mimarinin önemli örneklerinden biri olan AT\&T binası yıkılma tehlikesiyle karşı karşıyadır ve Norman Foster dahil pek çok kişi bu yıkıma karşı oluşan protestolara destek vermektedir.

Özel sermayenin finanse ettiği dünyevi mabetler, 21. Yüzyılda çok daha fazla sayıda, çok daha değişik, işlevsiz, kural tanımaz formlarda, arttk tüm dünyada, köksüz ulusaşırı patronajları kontrolünde, adeta mimarları ve eserlerini en çok ilgiyi üzerlerine çekmek için yarışa sokarcasına vücuda gelmeye başlamışlardır. Çalışanlarına, kullanıcılarına; modern, ayidiyet hissi veren mekanlar sağlama, plazaları ve lobileri kentin ayrılmaz bir parçası olarak düşünme fikri global olarak tüm dünyada demode hale gelmiştir. Çalışanların işlerinden çok işyerlerine ayidiyet hissetmesi, önlenmesi gereken bir durum olarak görülmüştür. Devamlılık, istikrar, iş güvenliği ve aidiyet olguları şirketlerce ve yerel yönetimlerce terkedilmiştir. Çünkü daha önce de belirttiğim gibi, mevcut siyasal-ekonomik sistem, başarı kıstaslarını değiştirmeye başlamıştır. Sonsuza kadar varolacağına inanılarak kamu kullanımı ve dinsel, kültürel ritüeller için yapılan anıtsal piramitlerin, zigguratların, katedrallerin yerini; uçuk kaçık, sükse yaratıp emlak piyasasını tırmandıran, bulunduğu kenti "mühürleyen", 30-40 yıllık kontratlarla kiralanan, ya da 2-3 sene kullanıldıktan sonra çok yük-

\footnotetext{
18 https://en.wikipedia.org/wiki/List_of_tallest_voluntarily_demolished_bu ildings
}

sek fiyatlara satilan ya da satilması gereken ofis binaları, alışveriş merkezleri, müzeler, tema parklar ve hatta karma kullanımlı yapay adalar almıştır.

Norman Foster'ın sigorta devi Swiss Re için tasarladığı, 2003 yılında 228.6 milyon sterline malolan ve "kornişon" takma adıyla medyada geniş yer bulan bina, şirketinin Londra'da yeni bir oyuncu olarak pozisyonunu güçlendirdikten ve üç yıl kullanıldıktan sonra bir Alman gayrimenkul grubuna 600 milyon sterline satılmıştı. Yine aynı bina, 2014 yılında da, 726 milyon sterline Brezilyalı yatırımcılara satılmıştı. ${ }^{19}$ Üstelik kornişon lakaplı bina, pekçok muadili gibi, pek de fazla doğal ışığın alımı, esneklik, mekanın randımanlı kullanımı gibi konularla öne çıkmamıştr. Bu binanın gündemi esas meşkul eden tarafi, yarattğı marka ve kimlik, ve kentte bir şirketle ilişkilendirilmiş olarak yarattğı güçlü imgelemdir. Neredeyse temel bir prensip gibi, yine, ikonik bir form iyi tasarlanmış rasyonel bir çalışma alanını hükümsüz kılmıştır. ${ }^{20}$ Gehry'nin tasarımı olan, bugüne kadar 17 milyondan fazla ziyaretçiyi ağırlamış ve yaklaşık 140 sergiye ev sahipliği yapmış Bilbao'daki Guggenheim Müzesi'de, Guggenheim vakfi tarafindan 20 yıllık lisans sözleşmeleriyle kullanılmaktadır. Müzenin yatırım ortaklarından olan Bask yerel yönetimi, müze içindeki resim koleksiyonları, yerin teminat, inşaat maliyeti, 20 yıllık işletme lisansı ve operasyon giderlerini kapsayan yaptığı 156 milyon avroluk yatırımın, artan konaklama, istihdam ve vergi geliri ile kaç yılda finansal geridönüşünün olacağıyla, yani yaptıkları yatırımın karşılığını ze zaman alacağıyla ilgili endişesiyle müzenin kentteki varlığını düşünmektedirler. ${ }^{21}$ Bir diğer deyişle, müze kentlilere ya da ziyaretçilerine verdiği hizmetten çok, sağladığı nakit akışıyla ve kente çektiği sermayeyle yerel yönetimin gündemini meşkul etmektedir. Tüm bu örnekler, belli süreçler için net bugünkü değerleri yani kapitalizasyonları hesaplanan yapılara nasıl tamamen kar odaklı bakıldığını, işletmesini aynı mekanda uzun yıllar bulundurmayan patronajı, aidiyetlik olgusunun şirketler ya da vakıflar için nasıl önemsizleştirilip terkedildiğini ve aslında yatıımcının stresini anlatması bakımından yeterlidir. Bu kapitalize edilme odaklı bakış açısı, ilk olarak yerin diferansiyel kapitalizasyonuyla süreci başlatmaktadır. Şehirdeki fiziksel mekan; ulusaşırı kapitalist elitler için, kapitalizasyon odaklı performans göstermesi gereken bir yatırım aracından başka bir şey değildir. Ve yarış böylesine kızışmışken; riske, nakit akışına ve değer hesabına hizmet etmeyen hiç bir boyut ya da aktör uzun süre varlığını sürdürememektedir. Öncelikli amaç; kentleri uluslararası yatırımcı için cazibe merkezi olarak korumak ya da cazibe merkezlerine dönüştürmek, uzamsal çözüm olarak yeni yatırım bölgeleri yaratmak, bu bölgelerde daha yüksek fiyatlara daha uzun süreler için kira sözleşmeleri yapabilmek, satarken binanın

\footnotetext{
${ }^{19}$ Jones, Sackley ve Watson, 2017, s. ${ }^{20}$ Sklair, 2017, s. 135.

276-287.
} 
değerini artttrarak satmak ve binadan daha fazla gelir elde etmek olmuştur. Örneğin bir şehir için, ulusaşırı yatırımcıyı ve yüzmilyonlarca dolarlık yatırımı kendi ülkesine çekebilecek özelliklerde olmak bir dünya şehri olmak demektir. Sassen'e göre dünya şehirleri yönetim ve kontrol merkezi olmalarından çok, finansal yeniliklerin açığa çıktı̆̆ı şehirlerdir. ${ }^{22} 80^{\prime}$ ler ve sonrasında da, sanayi kapitalizminden finans kapitalizmine geçişle; artık üretim, ve o üretimden elde edilen kazanç yerini, 'üretmeden' elde edilen kazanca bırakmaya başlamıştır. ${ }^{23}$ Ya da üretim, sermaye sahiplerinin kontrolünde, sermaye birikimi için bir araca dönüşmüştür. Böyle bir finasal yeniliğe de kent parçası en güçlü araç olmuştur. David Harvey kentleşmenin kapitalist formunu incelediği makalesinde, kent parçasının kendisinin bizzat en önemli sermaye birikim aracına dönüştüğünü ifade etmektedir. ${ }^{24}$ Başarılı bir yerel yönetim, tüm şehri ya da şehrin albenisini kaybetmiş bölgelerini, iş dünyası, kültür ve turist endüstrisi için yatırım yapılabilecek yerler haline getirebilen yönetim demek olmuştur. Asıl mesele; global bir firma yeni bir şirket binası temin etmek istediğinde, ünlü markalar sükse yaratacak mağazalar inşa ettireceklerinde, ya da bir müze yapısı hayata geçirileceğinde, bu yapıları finanse edecek her türlü özel sermayeyi ve yine özel ve kamusal fonu o şehre çekebilmektedir. Tüm varlıkların aynı oranda kapitalize edilmediği rekabetçi piyasa ortamına uzamsal boyutta bakıldığında, bölgesel olarak da kapitalize edilmede farklılıkların olduğu görülmektedir. Ve güç sahipleri bu değişken ve kaygan uzamsal boyutta tesadüfi olarak hareket etmemekte, bizzat bu zemini kendileri hazırlamaktadır. Gayrimenkul yatırım şirketleri, finansman sağlayan her türlü kuruluş, en büyük mimarlık-mühendislik şirketleri, politikacı ve bürokratlar, eğitimciler ve medya bu anlamda belirleyici rol oynamaktadır. Londra Belediye Meclisi'nin üzerinde artan ve onları çok katlı yapılaşmaya imkan tanıyan 2002 üniter gelişme planını hazırlamaya iten baskılar bu yüzdendir. Yine, dünyanın en büyük şirketlerini Londra'nın iş ve finans merkezi olan Square Mile Bölgesi'nde tutan, diferansiyel kapitalizasyon yarışında geri kalmamaktı. Bu yerel idari bölge, Londra'nın ve o bölgede faaliyet gösteren işyerlerinin imajını hergün yeniden çizmekte ve şehirdeki en yüksek emlak satış fiyatlarına ve en yüksek doluluk oranlarına sahip bulunmaktadır. Bu durumun, Bilbao Guggenheim Müzesi'nin tüm şehrin imajını yeniden çizmesinden ve köksüz ulusaşırı elitlerin lehine yaratılan yeni iş sahalarıyla şehrin ekonomik haritasını tamamiyle değiştirmesinden hiç bir farkı yoktur. Arap Riviyerası'nda inşaa edilen adalar bu anlamda çok dikkat çekicidir. Örneğin Katar Doha'da deniz, adeta küresel emlak sektörü için metalaştırılmıştır. Doha'yı küresel bir şehir yapmak için, Katar İnci Adası'nda gösteri mimarisi ve ikonik projeler araç olmuştur. ${ }^{25}$ Binlerce

\footnotetext{
22 Sassen, 1991.

${ }^{23}$ Lapavistas, 2013, s. 792-805.
}

konut projesini içinde barındıran ada, aynı zamanda Katar Şeyhi'nin mimarisini Pei'ye emanet ettiği İslam Eserleri Müzesini de içermektedir. Şeyh, mimarına bu müzenin tasarımı için "uç uçabildiğin kadar" demiştir. ${ }^{26} 300$ milyon dolara mal olan müzenin açılışına Katar Şeyhi ile Birleşik Arap Emirlikleri, Bahreyn ve Suriye liderleriyle birlikte, Robert De Niro ve Rolling Stones gitaristi Ronnie Wood gibi çok sayıda sanatçı katılmıştır. ${ }^{27}$ Böylece binanın tasarımı bir yana, sırf sükseli açılışı bile Doha'nın küresel piyasaya tanıtımına katkı sağlayan bir araca dönüştürülebilmiştir. Birleşik Arap Emirlikleri'nin bir parçası olan Abu Dabi sahiline 500 metre mesafede bulunan Saadiyat Adası ise bu yapay adaların en uç örneğidir. Geliştirici Aldar Şirketi en başından beri adanın kültürel bölgesini uluslararası arenada bir ikon olarak imgelemiştir ve kısa sürede bir ikonik bina koleksiyonu elde etmek projenin itici gücü olmuştur. ${ }^{28}$ Yüksek gelir grupları için tasarlanan Saadiyat Adası, yüzbinlerce kişilik konut kapasitesine, ve onlarca 5 yıldızlı otele sahiptir. Adanın Abu Dabi anakarasına bağlanması için inşa edilen köprü 163 milyon dolarlık bütçesiyle projenin ne boyutlarda olduğunu anlatması açısından önemlidir. Adadaki projeler, hepsi Pritzker ödüllü olan, Nouvel, Hadid, Koolhaas, Gehry, SOM, I.M.Pei, ve Shiguru Ban gibi mimarlara emanet edilmiştir. ${ }^{29}$ Jean Nouvel tasarımı Louvre Abu Dabi, Frank Gehry tasarımı Guggenheim Abu Dabi, Foster ve Ortakları tasarımı Zayed Ulusal Müzesi ve Zaha Hadid tasarımı Abu Dabi Gösteri Sanatları Merkezi, 85 milyon sterlinlik bütçesiyle Kültür Bölgesi'nde en öne çıkan yapılardır.

Norman Foster tasarladığı Şeyh Zayed Ulusal Müzesi'nin formunu, şeyhin şahin avcılığına merakından dolayı, şahin kanatlarına benzetmiştir. Jean Nouvel'in Abu Dhabi'deki Louvre Müzesi için tasarımı "bir uçan daire" formundadır. ${ }^{30}$ 2017 yııında en çok konuşulan mimari yapılarının başında gelen Louvre Abu Dabi, geçtiğimiz on yılda hakkında en çok yazılan (aynı zamanda eleştirilen) müzelerden biri olmuştur. Dış görünümünden sıkça söz edilen müze, Londra Times'ın 2017 yılının en heyecan verici binaları listesine aday gösterilmiştir. ${ }^{31}$ Louvre'un Abu Dabi'de hayata geçmesi için emirlik, dönemin cumhurbaşkanı Chirac ile antlaşma imzalamış ve Fransa'ya 1,6 milyar dolar ödeme yapmıştır. Bu antlaşma, Fransız aydınlarının "Louvre satılık değildir" diyerek ayaklanmalarına neden olduysa da, bu tepkiler projenin hayata geçmesine engel olamamıştr. ${ }^{32}$ Solomon R. Guggenheim Vakfi ile ortaklaşa hayata geçirilen Guggenheim Abu Dabi, kalıcı galerileri ve dinamik sergi programı ile çağdaş sanat merkezi haline dönüşmüştür. Hayata geçirilmesi için imzalanan 1 milyar avroluk sözleşmenin ardından geçen on yıldan sonra 2017'nin kasım ayında da açıl-

\footnotetext{
${ }^{26}$ http://artlog.art50.net/50 muze/ ${ }^{29}$ Jackson ve Dora, 2009, s. 2086-2104. ulusal-katar-muzesi $\quad{ }^{30}$ Artun, 2018, s. 18-19.

${ }^{27} \mathrm{http}: / /$ www.kalemguzeli.net/konu/ ${ }^{31} \mathrm{https}$ ://www.cso-consulting. katar-islam-eserleri-muzesi com/s/LOuvre-Abu-Dhabi.pdf

${ }^{28}$ Ponzini ve Nastasi, 2011, s. $58 . \quad 32$ Artun, 2018, s. 17.
} 
mıştr. ${ }^{33}$ Ali Artun, modernliğe ait her türlü sınırın, ölçünün, değerin aşıldığı bu 'hiper', 'süper', 'uç', 'yüksek', 'post' yaşamlara, kültür ve sanatla meşruiyet kazandırıldığı ve hatta bu lüks ve ifrat uygarlıklarının sanat aracılığıyla yüceltildiği ve bunun da bütün kamusal mirasın özelleştirildiği bir himaye ağı sayesinde başarıldığı tezini ortaya atmıştr. ${ }^{34}$ Gerçekten de mimarinin kendi bir "gösteri"ye dönüşerek, Olav Velthius'un çağdaş sanat sektörüne bir iktisatçı gözüyle baktığı ve "Hayali Ekonomi" adıyla özetlediği çalışmasında ortaya attğı gibi, sanatı metalaştırmak yerine metayı sanatsallaştrrmıştr. ${ }^{35}$ Peki tüm bu yüksek proje maaliyetleri, yıldız mimarlara tasarlatılmış 'enteresan' formlarda 'dünyevi mabetler', açılışlara katılan ya da gayrimenkul sahibi olan şöhretler, sükse yaratıp emlak piyasasını tırmandırır ve bulundukları şehri küresel ölçekte farkedilir kılarken, o kenti ya da yeri ne kadar yaşanılır kılmıştır? Denizin üstünde inşa edilmiş bu yapay adaların üzerlerindeki tüm yıldız mimar tasarımı bina koleksiyonları ve diğer tüm marina, golf sahası, lüks otel ve konut istifiyle birlikte, yoktan varedilmiş cazip bir yatırım 'üssüne' dönüştürülmüş olması, o yerde orantısız sermaye birikimi stratejisini mimarinin üzerine kurmuş olmaktan dolayı değil midir? Bu çalışma kapsamında yaptığım yarı-yapılandırılmış mülakatta görüştüğüm YTÜ mimarlık bölümü öğretim üyesi bu stratejiyi şu sözleriyle açıklamaktadır:

“Arap Emirlikleri'nde, çölün ortasında yeni yeni dünyalar kuruluyor. Ve yıldız mimarların tasarımları, bu yeni dünyaya değer katan yapılar olarak düşünülüyor. Çin ve Uzak Doğu'daki pek çok ülke için de benzer bir durum söz konusu. Dolayısıyla, bir anlamda sermayenin kendini gelişmekte olan ekonomilerde ve özellikle Uzak Doğu ya da Arap Emirlikleri'nde ifade etmesi mimari projeler üzerinden oluyor."

Hong Kong'da OMA'ya masterplanı hazırlatilan 40 milyar dolarlık Bat Kowloon Kültürel Bölgesi'nin ikonik bir kültür ve eğlence 'yer'ine dönüştürülmesinin; Panama'da, kentin imajını yeniden çizmesi ve pazarlanabilirliğini arttrması hedefiyle özellikle Frank Gehry'ye tasarlattrılan Biyolojik Çeşitlilik Müzesi'nin; ya da Napoli'nin güneyinde bulunan Salerno'da, kenti kültürel ve turistik aktiviteler için bir çekim merkezine dönüştürmek gayesiyle, Zaha Hadid'e tasarlatlan vapur iskelesi, Sejima ve Nishizawa'ya tasarlatlan kent parkı ve Chipperfield'e hazırlatılan tarihi kent merkezi yenileme planının arka planında yıldız mimarlar ve onların imza çizgilerinden umulan medet çok net değil midir? ${ }^{36}$

Yerin diferansiyel kapitalizasyonundan sonra, yapının diferansiyel kapitalizasyonu da tesadüflere bırakılmayan önemli bir parça olarak sürece dahil olmaktadır. Yani, hazırlanan ya da tanımlanan zeminde, binaların sahip oldukları özellikler, patronajı için kapitalize edilebildikleri ölçüde

\footnotetext{
${ }^{33}$ https://www.cso-consulting.com/s/LOuvre-Abu-Dhabi.pdf

${ }^{34}$ Artun, 2018, s. $16 . \quad{ }^{35}$ Velthius, $2005 . \quad{ }^{36}$ Sklair, 2017, s. 167.
}

var olabilmektedir. Ve yine burda da kapitalize edilebilen özelliklerin ne olduğu konusu kritik önem taşımaktadır. Bu çalışma kapsamında hazırlanmış arayüzde de belirtildiği gibi; rekabetçi yatırım imkanı tanıyan, değer/satış fiyatı/ kira artş̧ sağlayan, ün-marka değeri arttıran, kamunun desteğini alan, muhalefeti azaltan, kamusal ve özel fon bulma potansiyelini arttran, müşteri portföyünün kalitesini yükselten, kamuyla özel sermaye sahipleri arasındaki fikir ayrılıklarını azaltan, başka benzer projeleri tetikleyen işler başarılı kabul edilmişlerdir. Fakat bu özelliklerden hiç biri, genel anlamda, kentteki yaşam kalitesini arttrıcı bir rol oynamamaktadır. Mike Davis, Arap Emirlikleri'nde yoksul iş̧̧ilerin gözlerden uzak şantiyelerde tutularak, varlıklarının saklandığı ve dolayısıyla sadece varlıklı bireylerden oluşuyormuş gibi görünen şehirlerinde, adeta "servet sahiplerinin komünizmi" nin hüküm sürdüğünü söylemektedir. Ve, bu durumun "neoliberal ütopyanın bizzat kendisi" olduğunu ifade etmektedir. ${ }^{37}$ Londra, Mercer tarafindan 2017 de yapılan araştırmada, yaşam kalitesi indikatörlerine göre, Viyana'nın birinci olarak yer aldığı sıralamada, 40. olarak seçilmiştir. ${ }^{38}$ Bilbao şehrinde de, 2016 yılında müze tarafindan yayınlanan raporda, müzenin aktivitelerinden elde edilen gelirin 485.3 milyon avro olduğu ve Bask yerel yönetiminin hazinesine aktarılan paranın 65.8 milyon avro olduğu deklare edilmiştir. Yine yıllık ziyaretçi sayısının 1.169.404 olduğu belirtilmiş ve şehirde varlığını sürdüren işlerin sayısı da 9086 olarak ifade edilmiştir. ${ }^{39}$ Nüfusu 345.122 olan bir şehirde, bu denli çok ziyaretçinin yarattğı olumsuz etkiler ve kentliye yükü görmezden gelinecek gibi değildir. Ancak, kendi başına içinde sergilenenlerden bağımsız olarak, bulunduğu kente daha fazla ziyaretçiyi çeken ve daha fazla kamusal ve özel fon bulabilecek özellikte bir müze ve ya herhangi bir toplumsal fayda sağlama ihtiyacından kurtularak, şirket imajına katkı sağlayabilen, medyada yankı uyandırabilen, filmlerde yer bulan bir ofis binası; onlar için yerel ve merkezi yönetimlerce yapılan yatırımların karşılığını kent sakinleri için ödeyemeseler de, finans sektörü için fazlaca ödeyen son derece başarılı örnekler ve eşsiz firsatlardır.

\section{Kapitalizasyon Odaklı Yaklaşımın Kaçınılmaz Sonuçları: Toplumsal ve Tasarımsal Sabotajlar}

Yerin ve yapının kapitalize edilebilme dinamiklerini okuyabilen mimarlar, tasarımlarını bu anlamda yatırımcıya firsat ve avantaj tanıyan bir araç olarak kurgulayabildiğinde; bu çalışma kapsamında ifade edilen stratejik sabotajı yapmak için olanak sağlayan en etkin aktör olarak güç ilişkileri ağında yerlerini almaktadır. Küresel metropoller arası rekabette mimarlığın gücüne dikkat çeken Ali Artun, bu

\footnotetext{
37 Davis, 2006, s. 47-68.

${ }^{39}$ http://www.guggenheim-bil-

${ }^{38} \mathrm{https}: / / \mathrm{www}$.mercer.com/ bao corp.eus/wpcontent/uplonewsroom/2017-quality-of-living- ads/2011/06/Annual-Report-2016. survey.html pdf
} 


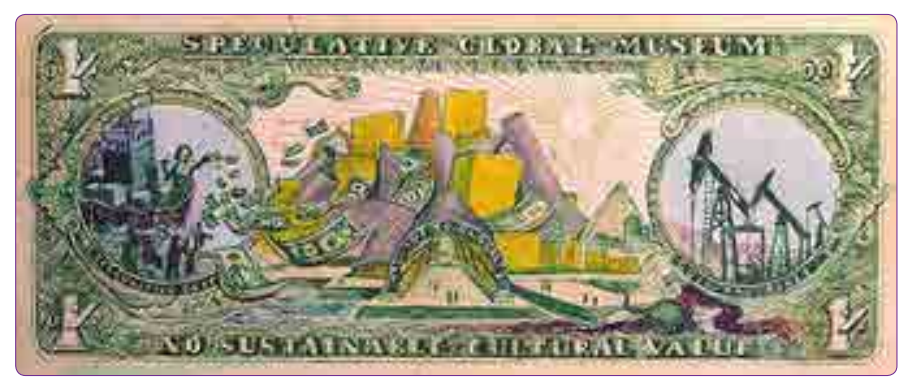

Şekil 2. Dramatik kültürel yatırımlara dikkat çeken Global Ultra Luxury Faction aktivist grubunun hazırladığı görsel. ${ }^{41}$

gücü değerlendirerek sivrilen bir avuç yıldız mimarın "postfordizm dönemi çılgınlığı" kentsel dönüşümün büyücüleri haline geldiğini ifade etmektedir. Mimarın neredeyse bütün işlevlerinden arınmış ve esas kaygısı spekülatif emlak piyasasını trmandırmak olan yapılar tasarlayarak yarattı̆ı değer artışının altını çizmektedir. ${ }^{40}$ Böylece tasarım da, çok başarılı bir sabotaj mekanizması olarak sisteme dahil olmaktadır. Burada sabote edilen değişim değeri yaratma gayesiyle, sağladığı gerçek toplumsal faydalardan ve kullanım değerinden başarısını ve gücünü alan mekanların üretimi olmaktadır. Kullanıcılarına, inşaatında ve işletmesinde çalışanlara, ait olduğu mahalleye, topluma, çevreye kazandırdıklarıyla yani kullanım değeriyle kendine bir yer edinmesi gereken mimari; spekülatif, arz talep dengesine göre her an farklılık gösteren, yatırımcının gözünden hesap edilen değişim değeri yaratma kaygısıyla, kışkırtıcı, seksi, baştan çıkarıcı tasarımlarla; herhangi bir olumsuz tepki çekmek ya da direnç oluşturmak bir yana; hem gidilip kullanılmasa dahi daha fazla ilgiye erişmiş; hem de patronajı dışındaki paydaşlara fayda sağlama zorunluluğundan da özgürleştirilmiştir (Şekil 2).

Guggenheim Abu Dabi Müzesi'nin inşaasındaki düşük iş̧̧i ücretlerini ve kötü çalışma koşullarını protesto etmek için Global Ultra Luxury Faction (G.U.L.F.) adlı bir aktivist sanat grubunun hazırladığı çarpıcı görsel, dramatik kültürel yatırımların ürünü olan, dünya üzerindeki servetin çok büyük bir kısmını elinde bulunduran ve nüfusun ancak \%1 ini oluşturan patronajın hayata geçmesini sağladığı mimariyi ve bu mimarinin toplumsal ve ekonomik boyutunu sorgulatması açısından başarılıdır. Burada bu çalışma kapsamında ası üzerinde durulan konu, binaların tipolojisinden öte, arayüzde belirtilen aktörlerin diferansiyel sermaye artşı ve şehirlerdeki diferansiyel büyüme lehine rekabetçi piyasa koşullarında üretilen her türlü "kamusal" mekanın, nasıl da o mekanı üreten, işleten, temizleyen ve yanıbaşında olup da bir defa bile içine giremeyen kent sakinleri için sabote edildiğidir.

Almanya Leipzig'de Zaha Hadid'in tasarladığı BMW Merkez Binası bu sefer kendi çalışanları için bir sabotaj

\footnotetext{
${ }^{40}$ Artun, 2018, s. 210.

${ }^{41}$ https://www.dissentmagazi-

ne.org/article/1-museum-theguggenheim-goes-global
}

aracına dönüşmektedir. Leipzig'in yakınlarında kurulan bu tesis için BMW, 1,6 milyar dolarlık inşaat masrafinın 454 milyon dolarlık kısmını $A B^{\prime}$ den sübvansiyon olarak temin etmiştir. Kalifiye iş̧̧i, ulaşım altyapısı ve esnek işgücüne sahip olan yer, tesadüfi olarak seçilmemiştir. Projenin hayata geçtiği zamanda, bölgedeki işsizlik oranı, yüzde 21 ile Bat Almanya'dakinin iki kat kadardır. Dolayısıyla BMW, işçi sendikalarıyla çalışma şartları için masaya oturduğunda eli güçlüdür. Bölgedeki yüksek işsizlik oranı sebebiyle, ülkedeki diğer BMW merkezlerindekinden yüzde 20 daha az maaşla işçi çalıştrmak önkoşulunu sendikalara kabul ettirir. Maaşlardaki kesintiye ek olarak, esnek çalışma saatleri, performansa göre ödeme yapma, ve yüksek oranda geçici iş̧̧i çalıştırabilme şartlarını da onatır. Ancak şirket bu sert şartlara rağmen, tesiste güçlü iletişim ve işbirliği, ve hiyerarşiden uzak bir yönetim düzeni varmış gibi görünmesini istediğinden, mimari tasarımın gücünden faydalanmıştır. Zaha Hadid'in kendine has çizgisini taşıyan, tüm çalışanların aynı kapıdan girdiği ve sosyalleşmek için aynı mekanı kullandığı bir plan şeması, güvencesizlikleri ve eşitsizlikleri örtbas etmede şirkete suç ortağı olmuştur. Ve böylece $A B^{\prime}$ den alınan maddi destekle önemli bir kısmı karşılanan pahalı, gösterişli ve sükseli mimari, sadece acımasız çalışma şartlarını hafifletmekle kalmamış, bir de üstüne işçilere apayrı ayrıcalıklara sahiplermiş gibi bir ortam yaratmıştır. ${ }^{42}$

Çin Pekin'de Rem Koolhaas tasarımı, şehrin önemli bir ikonu haline gelmiş CCTV Kulesi'ne giriş ücretleri öğle ve akşam yemekli opsiyonlarıyla farklılık göstermektedir. Bir başka bakış açısından, Ian Buruma'nın Guardian'daki makalesindeki sözleriyle, "bir milyar insana nasıl düşünmesi gerektiğini söyleyen bir aygıt olan devlet propaganda merkezi" OMA'nın güçlü ifade kabiliyeti, ve ikonik tasarımıyla şehirde tüketimciliği destekleyen bir röper, bir çekim noktası olmuştur. ${ }^{43}$ Pekin'e gelen turistlerin gezi rotalarında sıklıkla boy gösteren bir uğrak yeridir. Acaba Çin'in merkez radyo ve televizyon binası, böyle Rem Koolhaas'ın elinden çıkma "özel" bir tasarımı olmasa, yine bu kadar dikkat çekebilir miydi? Bulunduğu fakir muhitten tel örgüler ve duvarlarla kendini soyutladığı düşünülürse, bu pek mümkün görünmüyor. Aynı CCTV Kulesi gibi, Londra'daki "Kornişon" binasının girişleri de ücretli ve en üst katına grup olarak giriş 200 sterlindir. ${ }^{44}$ Yine civarda bulunan kulelerin seyir teraslarına, çat bahçelerine girişler biletli ve restoran ve barları ücretlidir. Yapılan bir ankette, Londra'nın kent simgeleri olarak en çok işaret edilen bu yapıların sokak kotunda tamamen kamu kullanımına kapalı ve en üst katlarında da spesifik kullanımlar için özelleşmiş, ziyaretçilerinden pek çok kurala uymasını talep eden, güvenlik kameralarıyla izlenen yerler olması; Londra Belediye Meclisi'nin yeni projeleri ancak kentsel mekan kullanımının güçlendirilmesi

\footnotetext{
${ }^{42}$ Spencer, 2018, s. 156-168. res11

${ }^{43}$ https://www.theguardian.com/ ${ }^{44}$ Kaika ve Thielen, 2006, s. 59-69. world/2002/jul/30/china.featu-
} 


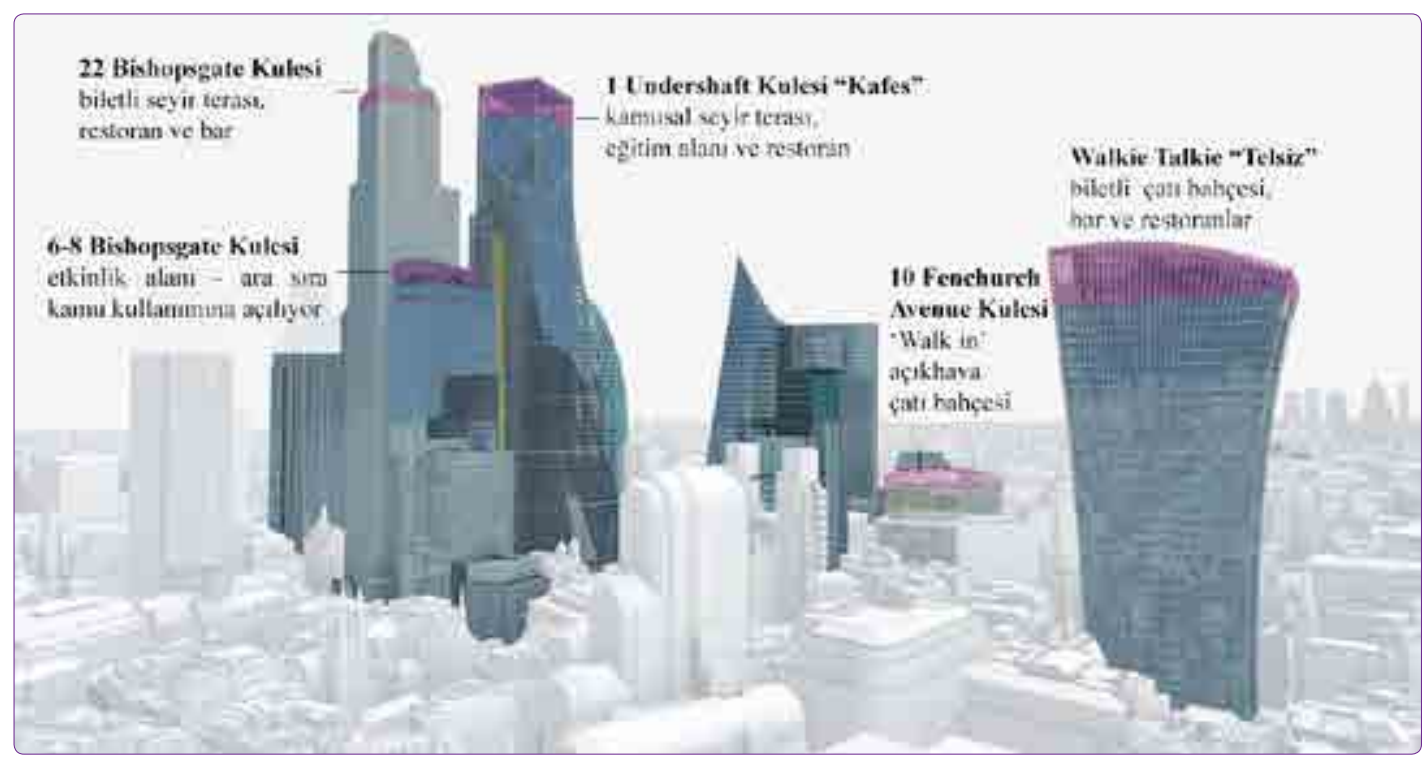

Şekil 3. Londra Square Mile Bölgesi'ndeki Kulelerin Gökyüzü Bahçeleri. ${ }^{46}$

koşuluyla onadığı düşünülürse, tam bir hayal kırıklığı olmaktadır ${ }^{45}$ (Şekil 3).

Andy Warhol'un "Tüm departman mağazaları bir gün müzeye dönüşecek ve tüm müzeler de departman mağazası olacak" dediği söylenir. Ve ne enteresandır ki, MoMA'nın müze dükkanında metrekare başına düşen satışın anahtar performans göstergesi, Amarika'nın en büyük süpermarket zinciri olan Walmart'ın metrekare başına düşen satışınınkinden daha fazladır. ${ }^{47}$ Bilbao Guggenheim Müzesi'nin de 13 euroluk giriş ücreti, gişe rekorları kıran ve çok ses getiren koleksiyonlar olduğunda finansman için ciddi bir katkı sağlamaktadır. Bu noktada, yerel halktan topladıkları vergileri ve kamu fonlarını, bu müzenin hayata geçmesi için harcayan yönetim, sorumlusu oldukları insanların kültürel etkinliklere erişimini bir nevi sabote etmektedir. Bu denli yüklü kamusal yatırımların, kültürel ve rekreasyonel aktiviteler için sınırlı bütçeler ayırabilen kentliler için ulaşılmaz olması maalesef sıradanlaşmış bir sabotaj halini almıştır.

Bu çalışma kapsamında görüştüğüm YTÜ Mimarlık Bölümü öğretim üyesi, yazıda sözünü ettiğim dünyevi mabetlerin yaratth̆ı toplumsal sabotajla ilgili farklı bir noktaya parmak basmakta ve bu "gösteri" mimarisiyle mekanın tüketildiğini, kentlinin kentle olan ilişkisinin kopartıldığını aşağıdaki gibi açıklamaktadır:

"Aslında bu kendi başlı başına ziyaretçi çeken yıldız mimarisi, sanat düşkünü ve orayı kullanmak isteyen vatandaşlar/ kişiler için itici bir hale gelmeye başlıyor bir süre sonra. Yaşadığı kentte bir sanat eserini ya da bir sergiyi görmek isteyen kentli, o turist kalabalı̆ıının içinde sıraya girmek zorunda kalıyor. Bu anlamda da, kentli için çok negatif

\footnotetext{
45 Kaika, 2010, s. 453-474.

of-london-skyline-of-tomorrow-

${ }^{46}$ https://www.theguardian.com/

artanddesign/2015/dec/11/city- ${ }^{47}$ Evans, 2003, s. 431.
}

bir durum bu. Arttk çok turistin geldiği ülkelerde, turizm istenmeyen bir şey haline gelmeye başladı. Çünkü mekanı tüketiyor. Orda yaşayan insanın, kentle olan ilişkisini kopartyor. Bazı mekanlar mesela, orda oturanlar tarafindan kullanılmak istenmiyor. Uzaklaşılıyor ordan gibi sonuçları da var. Kentliye de zararı olan bir şeyler var."

Bu yıldız mimarisinin, inşa edildiği kent ve kentli özelinde de farklı etkilerinin olacağına dikkat çeken YTÜ Mimarlık Bölümü Öğretim Üyesi, ayrıca şu tespitlerde bulunmaktadır:

İstanbul, Paris, Roma gibi tarihi geçmişi çok olan, kendileri zaten çok ön planda olan kentlerde, bu yapıların varlığı o kente bir şey katmıyor. Ha katabilir, belki bir tane bu mimarlardan bir tanesinin yaptığı bir örnek de, bir katman olarak yer alabilir. Ama İstanbul'a buna benzer yapıları çoğaltarak koymak aslında hiçbir şey getirmez. Tam tersi İstanbul'un var olan silüetini yok eder. İçinde yaşayan insanların aslında geçmişle olan izlerini yok etmeye başlar. Ölçek fikirlerini yok etmeye başlar. Kenti başka bir şeye evriltmeye başlar. Ve giderek de İstanbul gibi, geçmişi binlerce yıla dayanan bir kenti, bir süre sonra Arap Emirlikleri'ndeki bir kente, görgüsüz bir kente dönüştürmeye başlar. Özellikle bizimki gibi, eskiden çok çabuk vazgeçen, hep yeniyi arayan, hep yeninin güzel olduğunu düşünen, eskiyle ilişkisini çabuk koparan bir toplumda, bu mimari kentli üzerinde de çok negatif bir etki yarattr."

Yine görüştüğüm yüksek mimar da, yazıda savunduğum toplumsal sabotaj kavramını kendi sözleriyle şu şekilde açıklamaktadır:

"Mimarlık bir araçtır ve bu araç sermayenin amaçlarına hizmet etmeye başladığında toplumun ihtiyaçlarına hizmet etmekten ziyade bir gösteriş veya sükse aracı olarak maalesef kullanılmaktadır. Mimarlar da isteyerek ya 


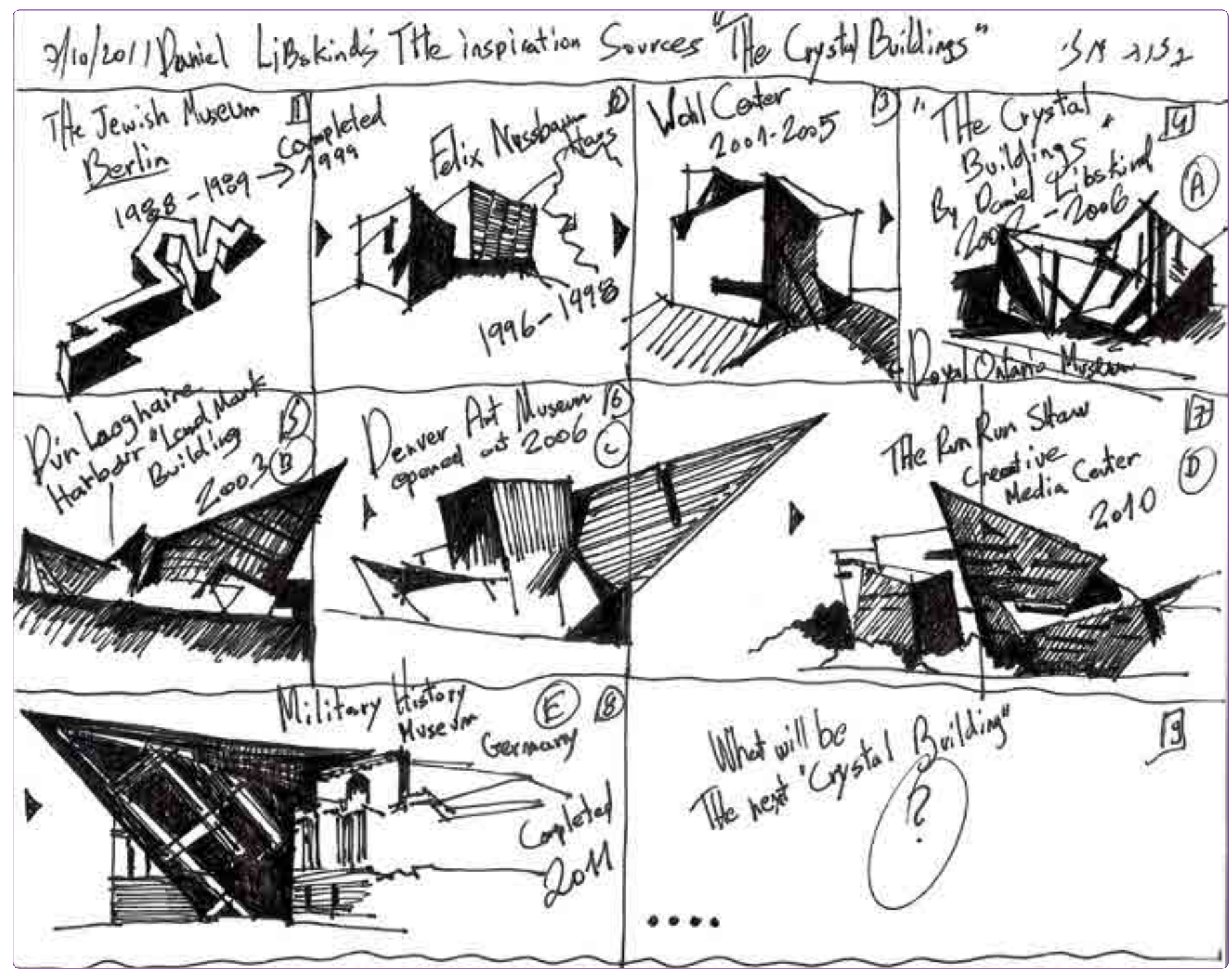

Şekil 4. Bir sonraki kristal bina ne olacak ${ }^{49}$

da istemeyerek buna alet olmaktadır. Burda uzun vadede gerçekten kentte bir değer oluşturup, sosyal ya da ekonomik bir geri dönüş olup olmayacağı konusunda planlı bir politika gerekli. Vatandaşın vergileri ve ülkenin özkaynaklarıyla finansmanının önemli kısmı sağlanan projelerin, kısa vadeli ve 'yatırımcı iştahı' odaklı kararlara bırakılmaması gerekmektedir."

Paranın ve teknolojinin dünyevi mabetlerinin kamu yararına kullanımının sabotajının yanında, sabote edilen aynı zamanda omuzlarında çok büyük yük taşıyan mimarın arkitektonik özgürlüğüdür. Bir şekilde bir kentte "tutmuş" bir mimari dil, diğer kentlerde de çok basit bir mantıkla talep görmüş ve mimarları da bu talebe karşı koyamamıştr.

Norman Foster Tasarımı "Kornişon" binasının formu bir sürü başka kulenin tasarımında tekrar edilmiştir. Barselona'da Jean Novel tasarımı Agbar Kulesi, Santiago Calatrava tasarımı "Şikago Helezonu", Hong Kong iş merkezindeki "Traş Makinesi" Kulesi bu açıdan örnek verilebilir.
Yine Gehry'nin titanyum heykelleri, Hadid'in agresif yılan motifi, BIG'in dağ konsepti, Liebeskind'ın kristal binaları farklı bağlamlarda, Baudrillard'ın "seri obje" kavramılla anlatmaya çalıştı̆ı, birbirinin benzeri yapıları oluşturmuş$\operatorname{tur}^{48}$ (Şekil 4).

Bu çalışma özelinde fikir paylaşımında bulunduğum akademisyen mimar yazıda belirtilen tasarımsal sabotajla ilgili görüşüyle yeni bir pencere daha açmakta ve şöyle demektedir:

"Çin ya da Arap Emrilikleri gibi ülkelerde, sanki bir yıldız mimarın yapısı oraya kondurulduğu zaman inanılmaz bir talep gelecek, kenti turistle dolduracak, ve değişik olduğu için çok bakılacakmış gibi, bir sürüsü, bir kolaj oluştururcasına yan yana getiriliyor. Böyle bir yaklaşım, bakış var. Mi-

${ }^{48}$ Baudrillard, 2010.

${ }^{49}$ h t t p s : / / a r c h i d i a I o g inspiration-sources-the-crystalcom/2011/10/08/daniel-libeskind- buildings/ 
marlar da bunu iyi biliyorlar ve bu formları tekrarlamak onlar için ticaret haline dönüşüyor. Tabi ki getirdiği yenilikler var ama dozajında kalması gerekiyor. Çünkü bir süre sonra kopyalanmaya başlıyor. Ve en kötüsü, öğrenciler de ortaya ben bu yapıyı çok beğendim diye çıkıyor. Ve aynı yapıyı sanki kendisi yapmak istermiş gibi bir tavır sergiliyor. Öğrenciler gibi, mimarlar da, dünyanın her yerinde bağlamından uzak bir şekilde bu yapıların bir benzerini tasarlıyorlar. Bir bakıyorsun, Gehry kopyası yuvarlatılmış köşeleri Van'da görüyorsun. Bu da, o yıldız mimarın yaptıklarının başka bir sonucu, çıktısı."

Yine bu çalışma için görüştüğüm yüksek mimar da, bu dünyevi mabetlerin yaratth̆ı tasarımsal sabotajı şu sözleriyle ifade etmektedir:

"Mimarın bir yapıyı tasarlarken kendine ait bir tarzının olması aslında kötü değildir. Asıl zorluk, daha sonra müşteri mimardan aynı tarz yapıyı başka yerde tasarlamasını istediğinde ortaya çıkar. Mimarın da bu zorlukla baş edip edemediği burada kritik önem taşır. Yani yatırımcı/ yüklenici, imza haline gelmiş bir formu başka bir yere bir 'Starbucks' formatında kopyalama talebiyle geldiğinde, o yapıyı mimarın kendi stilinde ama çevresine duyarlı, bulunduğu bağlamla özdeşleşecek ve işlevsel olarak da hakkını verecek şekilde tasarlaması, gerçekten mimar için her seferinde yeni bir sınavdır. Eğer yatırımcı mimar arasındaki bu ilişkiden mimar bu bahsettiğim niteliklerden taviz vermeden çıkabiliyorsa, o yapılar hem çevresine hem de kente katkı sağlayabilir diye düşünüyorum. Ancak piyasa koşulları, rekabet, maalesef tavizsiz bir tasarım sürecini mümkün kılamıyor her zaman."

Mimari teorisyen Mario Gandelsonas; dikkatin kent dokusu ve "yaşanan şehir" den kentin silüetine ve "izlenen şehir"e kaymasını, şehre anlam katan yeni boğum/düğüm noktaları yaratılması gayesiyle, yeni önemli kentsel imgeler kazandırma ihtiyacına verilmiş uygun bir tepki olarak açıklamıştır. ${ }^{50}$ Arttk soylu düğünleri, cenazeleri gibi gerçek ritüellere evsahipliği yapamayan bu dünyevi mabetler, toplumun sınırlı bir kesimini oluşturan medya çalışanları, mimarlar, yükleniciler, yerel yönetimler tarafindan "soyut ritüellere" konu edilmeye başlanmış ve yeni hayali semboller, anlamlar inşa edilmiştir. ${ }^{51}$ Toplumun Sanal Kurumsallaşması adlı başyapıtında, Castoriadis'in, işaret ve sembollerin yetilerini anlatırken "radikal sanal" olarak adlandırdığı kavramın ifade ettiği gibi, toplumlar ya da kolektiflerin henüz daha varolmayan bir şey için bir anlam evreni, bir yeni imajlar ve semboller dizisi kurabilme yetileri tam da burada ete kemiğe bürünmektedir. ${ }^{52}$ Mimariyi başlı başına neredeyse dini bir deneyim gibi medya organlarında sunma, başarılı olmuş orjinal tasarımların bir sürü "kopyasını" yaptırma, binaları objelere benzetip takma isimler verme,

\footnotetext{
${ }^{50}$ Gandelsonas, 1999, s. 63.
}

${ }^{51}$ Kaika, 2011, s. 968-992. mimarlarını birer medya yıldızı haline getirme, yüksek maaliyet - satış fiyatlarını başlı başına bir baştan çıkarıcı boyut olarak öne sürme, ve bu mabetleri sadece toplumun ayrıcalıklı üyelerinin kullanımına açma; gerçek ritüellerin yerini alan "soyut ritüeller" olmuştur. Ve bu soyut ritüeller, "gizemin gücünden" yararlanarak, aslında hiçbirine gerçekten bel bağlanmayan bir sürü olası anlam ve sembol önerisi sunmuştur. ${ }^{53} \mathrm{Bu}$ binalar kent genelinde kentlilerin günlük hayatlarına hiçbir değer katmadan; kent yaşamına katılmadan, uzaktan izlenen birer arzu objesine, hayal imgesine ya da ikona dönüştürülmüştür. Rekabetçi piyasa koşullarında kendine bir yer edinmek isteyen ve ya bulunduğu yeri korumak isteyen kentler, değerlerini yeniden belirlemek isteyen ülkeler, yeniden markalaşmak isteyen şirketler ve vakıflar tarafindan birer aracı olarak kullanılmıs ve kentteki fiziksel mekanın üretimini kapitalist elitlerin lehine stratejik olarak sabote eden bir düzeni ayakta tutmanın en güçlü aracı olmuştur.

\section{Son Değerlendirmeler}

Elbette bu çalışma kapsamında seçilmiş örneklere hızla büyüyen ve gelişmekte olan coğrafyalarda, büyük bir telaşla inşa edilen; uzamsal ve finansal boyutta nice dramatik sabotaj biçiminin gerçekleştiği daha sayısız örnek eklenebilir. Ancak mevcut örnekler; tüm bu üretimin ve tüketimin; yazıda, "metanın sanatsallaşması", "radikal sanal", "gizemin gücü" gibi kavramların yardımıyla ifade edilen sus pay(lar)ıyla; tepki oluşturmak bir yana neredeyse kutsanır hale getirilmesi olarak tanımlanan "sabotaj"। ifade eden bir çerçeve çizmesi açısından yeterli görülmüştür.

Kapitalin kritiği, en çok gelir bölüşümündeki eşitsizlik üzerinden yapılmaktadır. Mimarlık da; yeri, mekanı, malzemeleri, ayrıcalığı, erişimi, anlamı, hakları eşitsizce bölüştürerek; bu bölüşüm haksızlığına suç ortaklığı yapmaktadır. Mimar ve yapttğı iş, kapitalistlerin diferansiyel sermaye birikimine katkı sağlayabildiği kadar başarılı olmaktadır. Elle tutulamayan tüm fayda ve değerler, aslında finansal bir değer üretebildiği kadar rağbet görmektedir. Sanallık, gizem, görecelik gibi olgular, bu anlamda mimarı ve mimarlığı geçmişin sosyal sorumluluk içermek zorunda olan uygulama pratiğinden özgürleştirmekte, ve kapitalist mekan üretim biçimlerini olabildiğince renkli ve cezbedici bir "sabotaj" mekanizması haline getirmektedir. Kapitalist ekonomik ve politik sistem, potansiyel gördüğü her şeyi çoğaltıp büyütüp, kendi çarklarını döndürmek için kullanacağı itici bir güce dönüştürebilmektedir. Bir diğer deyişle, mimarının büyük emeği, özel becerisi ve adanmışlığıyla hayata geçen, çığır açan, ezber bozan projeler; kent parçasında orantısız sermaye birikimi elde etmek için kapitalist elitlerce yeni bir yöntem olarak benimsenip, seri bir şekilde arttırılabilmektedir. Dolayısıyla mimarların, mimari eleştirmenlerin,

\footnotetext{
53 Jencks, 2005, s. 223.
} 
teorisyenlerin, eğitimcilerin, bugün artk her zamankinden daha çok seçici ve dürüst olmaları gerekmektedir.

\section{Teşekkür}

Bu çalışma için olduğu gibi, doktora çalışmamda da, iklim değişikliğinin sektör tarafindan nasıl kapitalize edildiği ve yarattı̆ı sabotaj biçimleri ile ilgili yaptığım araştırmada bana yol gösteren "değerin güç teorisi"ni, incelememde ve anlamamda büyük katkıları olan doktora tez hocam Prof. Dr. Bernd Nentwig'e teşekkür ederim.

\section{Kaynaklar}

Adham, K. (2008) “Rediscovering the Island: Doha's Urbanity from Pearls to Spectacle", Ed.: Yasser Elsheshtawy (editor) The Evolving Arab City: Tradition, Modernity and Urban Development, Oxfordshire, Routledge, s. 218-257.

Artun, A. (2018) Çağdaş Sanatın Örgütlenmesi: Estetik Modernizmin Tasviyesi, İstanbul, Iletişim

Baines, J. (2017) "Accumulating through Food Crisis? Farmrs, Commodity Traders and the Distributional Politics of Financialization", Review of International Political Economy, Sayı 3, s. 497-537.

Baudrillard, J. (2010) Nesneler Sistemi, İstanbul, Boğaziçi Üniversitesi Yayınevi

Bichler, S., Nitzan, J. (2016) "A CasP Model of the Stock Market", Real-World Economic Review, Sayı 77, s. 119-154.

Castoriadis, C. (2012) The Imaginary Institution of Society, Brantford, W. Ross

Davis, M. (2006) "Fear and Money in Dubai", New Left Review, Sayı 41, s. 47-68

Evans, G. (2003) "Hard-Branding the Cultural City: From Prado to Prada", International Journal of Urban and Regional Research, Sayı:27, s. 417-440

Gandelsonas, M. (1999) X-urbanism: Architecture and the American City, New York, Princeton Architectural Press.

Harvey, D. (1975). "The Geography of the Capitalist Accumulation: A reconstruction of the Marxian Theory", Antipode, Sayı: 7, s. 9-21.

Harvey, D. and Gambetti, Z. (2008) Umut mekanları. İstanbul, Metis.

Howard, Philip H. (2016) Concentration and Power in the Food system: Who Controls What We Eat?. Contemporary Food Studies: economy, culture and politics, New York, Blumsbury Academic.

Jackson, M., Dora, V. (2009) " "Dreams so big only the sea can hold them": Man-made islands as anxious spaces, cultural icons, and travelling visions", Environment and Planning A, Sayı: 41, s. 2086-2104.

Jencks, C. (2005) The Iconic Building, New York, Rizzoli.

Jones, A., Sackley, W., Watson, E. (2017) “Teaching exchange rate risk using London's Gherkin building: How investors were in (and out of) a pickle", The Journal of Economic Education, Sayı 4, s. 276-287.

Kaika, M., Thielen, K. (2006) “Form follows Power”, City: Analysis of Urban Trends, Culture, Theory, Policy, Action, Sayı 10, s. 59-69.

Kaika, M. (2010) "Architecture and crisis: re-inventing the icon, re-imag(in)ing London and re-branding the City", Transacti- ons of the Institute of British Geographers, Sayı 35, s. 453474.

Kaika, M. (2011) "Autistic Architecture: the fall of the icon and the rise of the serial object of architecture", Environment and Planning D: Society and Space, Sayı 29, s. 968-992.

Koolhaas, R., Sigler, J., Mau, B. and Werlemann, H. (1998). Small, Medium, Large, Extra-Large. New Yok, Monacelli Press.

Lapavistas, C. (2013) "The financialization of capitalism: 'Profiting without Producing' ", City: Analysis of urban trends, culture, theory, policy, action, Sayı 17, s. 792-805

Larudee, M. (2011) "Book Review: Capital as Power: A Study of Order and Creorder", Review of Radical Political Economics, Sayı 3, s. 418-420.

Loe, E. (2000) The Value of Architecture, London, RIBA Future Studies.

Lorenz, D., \& Lützkendorf, T. (2008) "Sustainability in Property Valuation: Theory and Practice", Journal of Property Investment and Finance, Sayı 6, s. 482-521.

Macmillian, S. (2006) "Added Value of Good Design", Building Research and Information, Sayı 3, s. 257-271.

McMahon, J. (2015) "What Makes Hollywood Run? Capitalist Power, Risk and the Control of Social Creativity" Basılmamıs Doktora Tezi, York Üniversitesi, Sosyal ve Politik Düşünce Lisansüstü Programı.

Nitzan, J., Bichler, S. (2009) Capital as Power: A Study of Order and Creorder. London, Routledge.

Nitzan J., Bichler, S. (2007) War Profits, Peace Dividends, Hafia, Pardes.

Nitzan, J., Bichler, S. (2002) The Global Political Economy of Israel, Londra, Pluto Press.

Nitzan, J., Bichler, S. (2001) "Going Global: Differential Accumulation and the Great U-turn in South Africa and Israel", Review of Radical Political Economics, Sayı 33, s. 21-55.

Park, H-J., Doucette, J. (2016) “Financialization or Capitalization? Debating Capitalist Power in South Korea in the Context of Neoliberal Globalization", Capital \& Class OnlineFirst, s. 1-22.

Plaza, B. (2006) "The Return on Investmentof the Guggenheim Museum Bilbao", International Journal of Urban and Regional Research, Sayı 30, s. 452-467.

Ponzini, D., Nastasi, M. (2011) Starchitecture: Scenes, Actors and Spectacles in Contemporary Cities, Torino, Allemandi \& Co.

Sayce, S. (2004) "Incorporating Sustainability in Commercial Property Appraisal: Evidence from the U.K." The 11th European Real Estate Society Conference, Milano, Kingston Üniversitesi.

Sassen, S. (1991) The Global City: New York, London, Tokyo, New Jersey, Princeton University Press.

Sklair, L. (2017) The Icon Project: Architecture, Cities, And Capitalist Globalization, New York, Oxford University Press.

Spencer, D. (2018) Neoliberalizmin Mimarlığı: Çağdaş Mimarlığın Denetim ve İtaat Aracına Dönüşme Süreci, İstanbul, İletişim.

Velthius, O. (2005) Imaginary Economics: Contemporary Artists and the World of Big Money, Rotterdam, NAI Publishers

Zola, E. (1976) Oyun Bitti, İstanbul, Halk El Sanatları ve Neşriyat.

\section{İnternet Kaynakları}

https://archidialog.com/2011/10/08/daniel-libeskindinspiration-sources-the-crystal-buildings/ (Erişim Tarihi 1 Aralık 2017). 
http://artlog.art50.net/50_muze/ulusal-katar-muzesi (Erişim Tarihi 15 Nisan 2019).

https://www.cso-consulting.com/s/LOuvre-Abu-Dhabi.pdf (Erişim Tarihi 15 Nisan 2019).

https://en.wikipedia.org/wiki/List_of_tallest_voluntarily_demolished_buildings (Erişim Tarihi 1 Kasım 2017).

https://www.dissentmagazine.org/article/1-museum-theguggenheim-goes-global (Erişim tarihi 1 Aralık 2017).

http://www.guggenheim-bilbao-corp.eus/wpcontent/uploads/2011/06/Annual-Report-2016.pdf (Erişim Tarihi 1 Aralık 2017).

http://www.kalemguzeli.net/konu/katar-islam-eserleri-muzesi (Erişim Tarihi 15 Nisan 2019). https://www.mercer.com/newsroom/2017-quality-of-livingsurvey.html (Erişim Tarihi1 Kasım 2017).

https://www.theguardian.com/artanddesign/2015/dec/11/cityof-london-skyline-of-tomorrow-interactive (Erişim Tarihi 1 Aralık 2017).

https://www.theguardian.com/world/2002/jul/30/china.features11 (Erişim Tarihi 15 Nisan 2019).

\section{Yarı-Yapılandırılmış Görüşsmeler}

YTÜ Mimarlık Bölümü Bina Bilgisi Anabilim Dalı Öğretim üyesi (Görüşme Tarihi 17 Nisan 2019).

İstanbul Merkezli Uluslararası İnşaat Şirketi Çalışanı Yüksek Mimar (Görüşme Tarihi 10 Nisan 2019). 